\title{
The Effect of Willingness to Pay Taxes and the Level of Understanding of Taxpayers on Tax Payment Compliance
}

\author{
Sunariyah $^{1}$, Nur Huda ${ }^{2}$, Singgih Muheramtohadi ${ }^{3}$, and Tri Widyastuti Ningsih ${ }^{4 *}$ \\ 1,2,3,4 Universitas Islam Negeri Walisongo, Semarang, Indonesia
}

\begin{abstract}
This research aimed to know: 1). The effect of willingness to pay taxes on tax payment compliance in advertisement tax in Regional Revenue Agency (Bapenda) of Semarang. 2). The effect of the level of understanding of taxpayers on tax payment compliance in advertisement tax in Regional Revenue Agency (Bapenda) of Semarang. The data used in this research was primary data, in which the data source was obtained from questionnaires. The population in this research was the advertisement execution of taxpayers registered in Bapenda of Semarang City of 2017-2018. The research sample was 100 advertisement taxpayers, by using Slovin's method as the sample collection technique. The research findings show that 1). Willingness to pay taxes (X1) has a positive effect and significance on tax payment compliance $(Y)$ with a significance result of the score of 0.000 lesser than 0.05 . Therefore, the hypothesis of willingness to pay taxes (XI) is accepted ( $\mathrm{Ho}_{1}$ is rejected and $\mathrm{Ha}_{1}$ is accepted). 2). the level of understanding of taxpayers (X2) has a positive effect and significance on tax payment compliance $(Y)$ with the significance result of 0.007 score lesser than 0.05. Therefore, the hypothesis of the level of understanding of taxpayers (X2) is accepted $\left(\mathrm{Ho}_{2}\right.$ is rejected and $\mathrm{Ha}_{2}$ is accepted).
\end{abstract}

Keywords: Advertisement, Tax Payment Obedience, Understanding, Willingness.

\section{Introduction}

Indonesia is a large country that is divided into various regions consisting of provinces. The provinces are divided into cities and regency areas. Each city and regency have rights and obligations in the form of the authority to administer, regulate, and manage their territories independently without depending on the central government. To meet the needs of its region and governmental affairs, the region or areas has the authority to a collection of taxes or fees for local people. The tax collection conducted by the local government is regulated in the tax laws (Lubis, 2011).

The basis of Law Number 28 of 2009 concerning Regional Taxes and Regional Levies Article 1 point 10 indicates that regional taxes are identified as a form of compulsory contribution by individuals and entities which is regulated in the Constitution by not obtaining direct remuneration for taxpayers, functioning to finance regional needs for the welfare of local communities. Taxes collected by regions are contributed as a way of meeting the needs required for the regional government to be given to their regions. Therefore, it is called an autonomous region or regional autonomy. The autonomous region in question is a form of a regional government authority or freedom to manage and regulate its governmental affairs independently and not depending on the central government according to the unity and integrity of the NKRI system (Halim, Dara, \& Bawono, 2017).

Semarang City is one of the cities in Central Java in implementing its government system using the system of regional autonomy. In implementing regional autonomy, local governments should have prepared and planned the sources that will be used as regional revenue. The unpreparedness of the autonomous region has resulted in unoptimal gain of Locally-Generated Revenue (PAD) from these sectors. Local governments of cities or regencies should seek potential sources of local revenue to

* Corresponding author. Email address : tri_widyastutiningsih@walisongo.ac.id 
optimize it. However, the most significant aspect to increase and maximize PAD is to examine in depth the sectors that have the potential to be used as a source of PAD.

The following is data related to the target and realization of Locally-Generated Revenue (PAD) for the 2016-2018 budget of Semarang City Government:

Table 1 Target and Realization Data of Locally-Generated Revenue of Semarang City in 2016-2018

\begin{tabular}{|c|c|c|c|c|c|}
\hline No & Source of Revenue & Year & $\begin{array}{l}\text { Target } \\
\text { (IDR) }\end{array}$ & $\begin{array}{l}\text { Realization } \\
\text { (IDR) }\end{array}$ & $\begin{array}{c}\text { Percentage } \\
(\%)\end{array}$ \\
\hline \multirow{3}{*}{1.} & \multirow{3}{*}{ Local Tax } & 2016 & $886,964,751,000$ & $988,944,372,059$ & 111,5 \\
\hline & & 2017 & $1,111,750,000,000$ & $1,231,515,123,563$ & 110,77 \\
\hline & & 2018 & $1,238,450,000,000$ & $1,331,817,414,862$ & 107,54 \\
\hline \multirow{3}{*}{2.} & \multirow{3}{*}{ Regional Levies } & 2016 & $127,522,601,000$ & $119,299,815,523$ & 93,6 \\
\hline & & 2017 & $121,424,495,000$ & $85,744,858,357$ & 70,62 \\
\hline & & 2018 & $148,364,420,000$ & $107,822,774,730$ & 72,67 \\
\hline \multirow{3}{*}{3.} & \multirow{3}{*}{$\begin{array}{l}\text { The results of } \\
\text { management of } \\
\text { separated regional } \\
\text { assets }\end{array}$} & 2016 & $51,979,633,000$ & $52,309,979,748$ & 100,6 \\
\hline & & 2017 & $28,489,560,840$ & $28,491,561,139$ & 100,01 \\
\hline & & 2018 & $45,084,724,000$ & $42,552,117,491$ & 94,38 \\
\hline \multirow{3}{*}{4.} & \multirow{3}{*}{ Other Legal PADs } & 2016 & $270,082,744,002$ & $308,736,746,562$ & 114,3 \\
\hline & & 2017 & $430,735,045,282$ & $446,134,835,615$ & 103,58 \\
\hline & & 2018 & $379,453,144,800$ & $362,061,916,732$ & 95,42 \\
\hline
\end{tabular}

Source: Regional Revenue Agency of Semarang City, Processed in 2020

Based on the data from the table above, the realization of Locally-Generated Revenue is originated from the five sources of Locally-Generated Revenue. The highest revenue is found in the realization of local taxes when compared to other sources of revenue. Regarding the realization of Locally-Generated Revenue of Semarang City in 2016-2018, which is explained in table 1.1, this realization has fluctuated, where there has been an increase and decrease year by year in the source of revenue. The data for the last three years obtained show that in 2017 and 2018, the source of revenue from local revenue has decreased, except regional levies which have increased in 2018 , amounting to $72.67 \%$. When seen from the budget target and realization, many revenue sources have not yet reached the target budget as seen from the declining percentage

Local taxes are the largest contribution to Locally-Generated Revenue. It can be seen in table 1.1. For instance, in 2018, the local tax was realized in the amount of IDR $1,331,817,414,862$. It adds to the source of income to the Locally-Generated Revenue of Semarang City. This realization is the biggest achievement when compared to the realization of other achievements, such as Regional Levies of IDR. 107,822,774,730, the results of management of separated regional assets of IDR 42,552,117,491, and Other Legal PADs of IDR 362,061,916,732. It proves that the contribution given by regional taxes to local government has a significant effect that local taxes have more ability to manage regional finances in financing regional households.

Semarang City is one of the metropolitan cities that has good potential from the economic, social, tourism, and other sectors. Therefore, many entrepreneurs and/or 
business people and indigenous people in Semarang take advantage of this situation as a business opportunity. Business actors in Semarang can introduce, promote, or attract general attention to their products by utilizing advertising as a technique to attract the attention of potential consumers so that products will be sold and obtain income from product sales. Therefore, it can be said that the metropolitan city of Semarang is a large area of the billboard or advertising sector. Regional Regulation of Semarang City Number 6 of 2011 concerning Advertising Tax states that the advertisement tax object is an individual or entity that organizes billboards in Semarang City. These advertisements include: 1). Advertisements in the form of boards/billboards/Videotron/Megatron and the like 2). Advertisements in the form of fabrics 3). Advertisements attached/stickers 4). Advertisements in the form of leaflets 5). Walking advertisements on vehicles 6). Advertisements being flown on the air 7). Floating advertisements 8). Advertisements in the form of sound 9). Advertisements in the form of films/slides and the like 10). Advertisements in the form of a demonstration. Meanwhile, the subject of advertisement tax consists of individuals or entities that organize advertisements in Semarang City. If the advertisers are organized through a third party, the third-party becomes the advertisement taxpayer who is obliged to pay the advertisement tax (Perda Nomor 973/90 Tahun 2012).

The data related to the data on the realization of advertisement tax revenue of Semarang City in 2016-2018 are as follows:

Table 2 Realization Results of Advertising Tax Revenue of Semarang City in 2016-2018

\begin{tabular}{cccc}
\hline Year & Budget Target (IDR) & Realization (IDR) & Percentage (\%) \\
\hline 2016 & $28,135,001,000$ & $29,156,573,475$ & 103.6 \\
\hline 2017 & $31,000,000,000$ & $28,899,109,922$ & 93,2 \\
\hline 2018 & $35,000,000,000$ & $24,897,941,656$ & 71,1 \\
\hline \multicolumn{5}{c}{ Source: Regional Revenue Regency of Semrang City, Processed in 2020 }
\end{tabular}

Based on the data above, it can be seen that from 2016-2018, the realization of advertisement tax revenue had decreased significantly. The advertisement tax was not able to reach the target compared to the amount that has been budgeted. The percentage of realization from 2016-2017 decreased by $10.4 \%$ and in 2017-2018, the realization declines again, reaching $22.1 \%$. It is certainly a new problem for the Semarang City Government related to the source of revenue for PAD of Semarang City.

Research related to the effect of the willingness to pay taxes and the level of understanding of taxpayers on tax compliance includes research from Agustiningsih and Isroah (2016) showing that there is a positive and significant effect on the level of understanding of taxpayers on tax compliance. However, the results of these studies are different from those conducted by Arisandi (2017), stating that there is significantly no effect of the level of understanding of taxpayers on tax compliance.

Based on the explanation above, there is a discrepancy in the research results. Therefore, the researchers intended to develop and explore from the previous study by researching the Regional Revenue Agency (Bapenda) of Semarang City, an empirical study on the advertisement tax sector in Semarang City. The difference between this study and the study conducted by Agustin is the case study used. Therefore, the authors conducted a study entitled "The Effect of Willingness to Pay Taxes and the Level of Understanding of Taxpayers on Tax Payment Compliance (A Case Study: On Advertising Taxpayers Registered at the Regional Revenue Agency (Bapenda) of Semarang City)".

\section{Literature Study/Hypotheses Development}

Tax

Tax according to Law Number 16 of 2009 concerning General Provisions and Tax Procedures is a contribution from an individual or entity owed to the state which can 
be imposed without receiving direct compensation for taxpayers according to existing government regulations, to finance state households and to maintain the prosperity of society in general.

\section{Advertisement Tax}

Advertisements are used to introduce and promote a product or service aiming that the product can be seen, recognized, and used by many people, made of media objects or tools, except advertisements organized by the government. In essence, the advertisement tax is a regional (city/regency) tax, but for regions that do not have a city/regency such as Jakarta, according to Law Number 18/1997, the regional tax for this region is a combination of taxes from provincial and city/regency areas.

Advertisements that are organized by individuals or bodies and individuals or bodies are directly carried out by themselves. If the advertisement is organized through a third party, then the third party becomes the advertisement taxpayer. Meanwhile, the highest tax rate on advertisement organizers is at $25 \%$ (stipulated by regional regulations).

The basis for the imposition of tax rates and the calculation of the advertisement tax of Semarang City is in accordance with the Regional Regulation of Semarang City Number 6 of 2011 concerning Advertisement Tax. Based on this regulation, the basis for the imposition of advertisement tax is:

1. The rental Value of Advertisements (NSR) based on the Decree of the Mayor of Semarang Number 973/90 of 2012 concerning the Determination of the Rental Value of Advertisements in Semarang City

2. The advertisement organizer's tax rate is imposed by a third party according to the contract value of the advertisement

3. The amount of the advertisement organizer's tax rate that is carried out independently is calculated according to the type of material used in the advertisement, the place where the advertisement is installed, the period, and the area of the advertisement area.

4. The rental Value of Advertisements is calculated by multiplying the advertisement creation by the strategic value of the advertisement installation, the total number of advertisements, the width of the advertisements, and the time they are installed.

5. Calculation of the value of advertisement creation is according to the type of material for making the advertisements.

6. Determination of strategic value for the installation of the advertisements is according to the area where the advertisements are installed and the strategic location for the installation of the advertisements.

7. Determination of the location for the installation of the advertisements and the strategic location for the installation of the advertisements is according to the point where the advertisements are installed based on road area, road conditions, and density angles.

\section{Attribution theory}

Attribution theory is a theory that can explain the process of how we know the causes and motives arising from a person's behavior (Newcomb \& Heider, 1958). This theory is highly appropriate to explain the factors affecting the level of taxpayer compliance that will be used in this study. Taxpayer compliance can be related to the attitude arising from the taxpayers to provide an assessment of the tax. Internal and external factors will affect a person in assessing other people and particular events (Azyarah, 2017). In this study, the researchers used attribution theory to find out the factors that could affect the level of taxpayer compliance.

\section{Theory of Planned Behavior (TPB)}

Based on the TPB model according to Ajzen, individual behavior to disobey tax provisions is affected by the intention to behave disobediently. The intention to behave 
The Effect of Willingness to Pay Taxes and the Level of Understanding of Taxpayers on Tax Payment Compliance

is affected by three factors, including: behavioral belief, normative belief, and control belief (Hidayat \& Nugroho, 2010).

\section{Taxpayer Willingness}

The concept of willingness to pay taxes is defined as a value that someone is willing to contribute (which is determined by the rules) to be used to finance general state expenditures without receiving direct reciprocal services. Willingness to pay taxes is a value in which someone is willing to pay, sacrifice, or exchange something to obtain goods or services (Nugroho \& Zulaikha, 2012). Willingness to pay taxes is affected by several factors, including the condition of a country's tax administration system, services to taxpayers, tax law enforcement, and tax rates (Hardiningsih, 2011).

\section{Taxpayer Understanding}

According to Zulaikha (2013), taxpayer understanding about taxation regulations is an internal cause that can affect the perception of taxpayers in making decisions regarding taxpayer compliance behavior in performing tax obligations. Based on social learning theory, taxpayers can learn through observation and direct experience regarding the role of understanding that taxpayers have about tax regulations in helping taxpayers to fulfill tax obligations. If the obligation to register has been fulfilled, then the taxpayers must calculate, count, pay, and self-report the amount of tax owed. These obligations must be performed in accordance with the prevailing laws and regulations (Masruroh \& Zulaikha, 2013).

According to Nurlaela (2013) argued that taxpayers should know and understand the following tax regulations:

1. Knowledge and understanding of the rights and obligations of taxpayers. Alternatively stated, taxpayers will perform their tax obligations and rights if they know and understand their obligations as taxpayers.

2. Ownership of Taxpayer Identification Number (NPWP), as a means to streamline tax administration, taxpayers who already have income are obliged to register themselves to obtain a Taxpayer Identification Number.

3. Knowledge and understanding of tax sanctions of the taxpayers who already have knowledge and understanding of tax sanctions. The taxpayers will be more obedient and compliant in performing their tax obligations.

4. Knowledge and understanding of PKP, PTKP, and tax rates. Taxpayers who know and understand the applicable tax rates will be able to calculate the tax owed properly and correctly.

5. Taxpayers know and understand the tax regulations that can be obtained through socialization performed and implemented by KPP.

6. Taxpayers know and understand tax regulations obtained through training on taxation that is followed by brands (Ilhamsyah, Endang, \& Dewantara, 2016).

\section{Taxpayer Compliance}

Taxpayer compliance can be interpreted as a situation where taxpayers can be responsible for meeting their obligations and rights in performing their taxation. The issue of compliance is essential because concurrent non-compliance can lead to tax evasion, resulting in reduced tax funds depositing into the state treasury. Based on this explanation, it can be concluded that the higher the level of truth in calculating the amount of tax, the accuracy in terms of depositing and filling in and submitting a notification letter, the more compliant the taxpayer is in fulfilling their tax obligations. Types of taxpayer compliance are:

1. Formal Compliance

A situation where the taxpayer meets their obligations formally in accordance with the provisions of the taxation law.

2. Material Compliance 
A situation in which the taxpayer substantially meets all the material tax provisions, that are based on the content and spirit of the tax law, material compliance can also include formal compliance.

\section{Hypotheses Formulation \\ The Effect of Willingness to Pay Taxes on Tax Payment Compliance}

Theory of Planned Behavior explains that individual behavior towards tax provisions is affected by the intention to behave obediently or compliantly. The intention to behave is due to the factors that affect the taxpayer's behavior. One of the factors is a behavioral belief, where a willingness in a person comes from a belief in the outcome of behavior (outcome belief) and an evaluation of the outcome of that behavior. Beliefs and evaluations of these results will shape the attitude variables towards that behavior. Willingness to pay taxes is one of the factors of behavioral belief.

According to research by Hutabarat, Ratnawati, and Julita (2018), factors affecting the willingness of taxpayers to pay their tax obligations include taxpayer awareness, taxpayer knowledge, tax office service quality, taxpayer understanding of taxation, and tax penalties. The willingness of taxpayers to pay their tax obligations is essential to increase the source of tax revenue. Meanwhile, according to research conducted by Agustin and Khairani, the willingness to pay taxes has no significant effect on tax compliance. Based on the results of previous studies which show inconsistent results, the first hypothesis proposed by the researchers is as follows:

\section{$H_{I}$ : Willingness to pay taxes has a positive effect on tax compliance}

\section{The Effect of the Level of Understanding of Taxpayers on Tax Payment Compliance}

Theory of Planned Behavior is a theory that explains individual behavior. Individual behavior is affected by several factors. One of these is a control belief. Control belief is an individual's belief about the existence of aspects supporting or hindering their behavior and perception of how strongly these aspects influencing their behavior. The understanding of taxpayers is one of the factors of control belief. Taxpayers' understanding of tax regulations will support their confidence in determining their behavior to perform their obligations as obedient taxpayers.

Agustiningsih and Isroah (2016) stated that the level of understanding of taxation is seen from how much they understand the applicable tax provisions. Taxpayers who have a high level of understanding of taxation will reduce the level of violation of tax regulations and increase the level of taxpayer compliance (Agustiningsih \& Isroah, 2016). Therefore, the higher the level of understanding of taxation, the higher the taxpayer compliance. This statement is supported by the results of research conducted by Candrakusuma (2018) that understanding the taxation system has a positive and significant effect on advertisement taxpayer compliance. However, it is in contrast to the results of research conducted by Nurlaela (2014), showing that knowledge and understanding of tax regulations do not significantly affect compliance with the willingness to pay taxes. It proves that the respondents are not aware that paying taxes is a crucial matter for the country. Based on the inconsistent results of the previous studies, the second hypothesis proposed by the researchers is as follows:

\section{$\mathrm{H}_{2}$ : The level of understanding of taxpayers has a positive effect on tax} compliance

\section{Research Methodology}

This study used a quantitative method with a survey research form. This study used two types of variables including dependent and independent variables. Independent variables in this study are willingness to pay taxes and level of understanding of taxpayers while the dependent variable is tax payment compliance. 
Sources of data to be used were primary data through questionnaires and secondary data obtained from advertisement taxpayer data registered with the Regional Revenue Agency (Bapenda) of Semarang City.

The data collection method in this study was performed by distributing questionnaires. The questionnaire that was distributed was related to the problem which was the object of the research. This questionnaire was distributed to advertisement organizers in Semarang City.

\section{Results}

\section{The Effect of Willingness to Pay Taxes on Tax Payment Compliance}

Based on the results of data processing, the results of this study indicate that the willingness to pay taxes $(\mathrm{X} 1)$ has a positive effect on tax compliance (Y). If the level of willingness to pay taxes by taxpayers increases, it will certainly affect the level of tax payment compliance. When there is a will, there is a way, indicating that when a taxpayer has the willingness to pay their tax obligations, it will be easier to pay taxes so that the level of tax compliance will increase by $0.695(69.5 \%)$. In conclusion, the hypothesis of the variable of willingness to pay taxes (X1) is accepted $\left(\mathrm{H}_{\mathrm{ol}}\right.$ is rejected, $\mathrm{H}_{\mathrm{a} 1}$ is accepted).

\section{The Effect of the Level of Understanding of Taxpayers on Tax Payment Compliance}

The result of the regression equation coefficient of the level of understanding of the taxpayers (X2) is positive of 0.205 , indicating that there is a positive effect on the level of understanding of the taxpayers (X2) on tax compliance. The level of understanding of the taxpayers (X2) can explain compliance with paying taxes of 0.205 (20.5\%). The result of the determination coefficient of 0.724 shows the willingness to pay taxes and the level of understanding of the taxpayers can explain $72.4 \%$ of tax compliance. Based on the above results, the hypothesis of the level of understanding of taxpayers (X2) is accepted $\left(\mathrm{H}_{02}\right.$ is rejected, $\mathrm{H}_{\mathrm{a} 2}$ is accepted).

\section{Discussion}

The results of data analysis tests that have been performed by the researchers show quite good findings. These results can be explained as follows. First, the results of the partial hypothesis testing of the t-test of the value of the willingness to pay taxes (X1) of 0.000 was less than the value of $\alpha=0.05$. It indicates that the willingness to pay taxes (X1) partially and significantly affects tax compliance (Y).

Second, the results of testing the hypothesis simultaneously using the f test. The results of the f test of the willingness to pay taxes (X1) and the level of understanding of the taxpayers (X2) have a significance value of 0.000 . It indicates that the independent variables together have a significant effect on tax compliance (dependent). Third, the value of the willingness to pay taxes (X1) was 0.695 , indicating that the willingness to pay taxes (X1) positively affects the level of tax compliance (Y).

The results in this study are in accordance with those conducted by Hutabarat, Ratnawati, and Julita (2018) that the hypothesis of taxpayers who have a positive perception will make taxpayers tend to act on their willingness to pay their obligations to pay taxes. Meanwhile, if a negative perception appears in the taxpayers, there will be a willingness to avoid their obligation to pay taxes. In fact, it will affect the level of decline in tax compliance. The more taxpayers are willing to pay their taxes, the more obedient the taxpayers in paying their tax obligations.

Based on the results of partial hypothesis testing using the t-test, the level of understanding of taxpayers (X2) shows a significant result of 0.007 . This result is less than the value of $\alpha=0.05$, indicating that partially, there is a significant effect on the level of understanding of taxpayers on tax compliance. It shows that the more the 
taxpayer understands about their obligation to pay taxes, the more it affects the level of tax payment compliance.

Based on the results of the partial hypothesis testing of the t-test, the level of understanding of taxpayers (X2) shows a significant result of 0.007 . This result is less than the value of $\alpha=0.05$, indicating that partially, there is a significant effect on the level of understanding of taxpayers on tax compliance. It shows that the more taxpayers understand about their obligation to pay taxes, the more it affects the level of tax payment compliance.

The result of the regression equation coefficient of the level of understanding of the taxpayers (X2) was positive of 0.205. It indicates that there is a positive effect on the level of understanding of the taxpayers (X2) on tax compliance. The level of understanding of the taxpayers (X2) can explain compliance with paying taxes of 0.205 (20.5\%). The result of the determination coefficient of 0.724 shows the willingness to pay taxes and the level of understanding of the taxpayer can explain $72.4 \%$ of tax compliance. Based on the above results, the hypothesis of the level of understanding of taxpayers (X2) is accepted $\left(\mathrm{H}_{\mathrm{o} 2}\right.$ is rejected, $\mathrm{H}_{\mathrm{a} 2}$ is accepted).

The results above are supported by the results of research conducted by Hermawan (2014) that the level of understanding of taxpayers about the regulations shows a significant value of 0.001 less than the value of $\alpha=0.05$, indicating that the level of understanding of taxpayer about the regulations significantly affects taxpayer compliance. The higher the level of understanding of the taxpayers shows a positive impact on the level of tax payment compliance. It is in line with research conducted by Mahaputri and Noviari (2016). The results of the hypothesis show that the understanding of tax regulations has a positive effect on taxpayer compliance. Therefore, the better the level of understanding of the taxpayer, the better the compliance to pay taxes and increase the source of tax revenue.

The effect of the level of understanding of taxpayers makes the taxpayers tend to be more obedient to comply with their obligations as obedient taxpayers. If taxpayers can better understand the obligations of taxpayers as good citizens, understand tax regulations and the tax sanctions that will be received if they do not fulfill their tax obligations, it will certainly increase the level of willingness to pay taxes so that compliance with paying taxes will continue to improve well.

\section{Conclusion}

Based on the results of the analysis of research data, it can be concluded that the willingness to pay taxes and the level of understanding of the taxpayers affect tax payment compliance. These results indicate that the Directorate General of Taxes has a role in disseminating the rules and sanctions that will be obtained for taxpayers. With this socialization, it is expected that benefits can be obtained and felt by taxpayers so that it is expected to increase taxpayer compliance.

\section{References}

Agustin, D., \& Khairani, S. Pengaruh Kemauan Membayar Pajak Dan Tingkat Pemahaman Wajib Pajak Terhadap Kepatuhan Membayar Pajak (Studi Empiris Pemilik Kos Yang Terdaftar Di Badan Pengelolaan Pajak Daerah Kota Palembang).

Agustiningsih, W., \& Isroah. (2016). Pengaruh Penerapan E-Filling, Tingkat Pemahaman Perpajakan Dan Kesadaran Wajib Pajak Terhadap Kepatuhan Wajib Pajak Di KPP Pratama Yogyakarta. Nominal, 5(2). 
The Effect of Willingness to Pay Taxes and the Level of Understanding of Taxpayers on Tax Payment Compliance

Arisandy, N. (2017). Pengaruh Pemahaman Wajib Pajak, Kesadaran Wajib Pajak Dan Sanksi Pajak Orang Pribadi Yang Melakukan Kegiatan Bisnis Online Di Pekanbaru. Jurnal Ilmiah Ekonomi dan Bisnis, 14(1), 62-71.

Azyarah, F. B. (2017). Pengaruh Penerapan Sistem E-registration E-SPT dan E-filling Terhadap Kepatuhan Wajib Pajak Orang Pribadi Pada KPP Pratama Semarang Timur. [Skripsi]. Semarang: Universitas Dian Nuswantoro.

Candrakusuma, A. R. (2018). Analisis Determinan Pada Kepatuhan Wajib Pajak Reklame Yang Terdaftar Di Badan Pengelolaan Keuangan Dan Aset Daerah Kota Yogyakarta. [Skripsi]. Yogyakarta: Universitas Islam Indonesia.

Halim, A., Dara, A., \& Bawono, I. R. (2017). Perpajakan. Jakarta Selatan: Salemba Empat.

Hardiningsih, P. (2011). Faktor-Faktor Yang Mempengaruhi Kemauan Membayar Pajak. Dinamika Keuangan dan Perbankan, 3(1), 126-143.

Hidayat, W., \& Nugroho, A. A. (2010). Studi Empiris Theory of Planned Behavior Dan Pengaruh Kewajiban Moral Pada Perilaku Ketidakpatuhan Pajak Wajib Pajak Orang Pribadi. Jurnal Akuntansi dan Keuangan, 12(2), 82-93.

Hutabarat, R. H., \& Ratnawati, V., \& Julita. (2018). Faktor-Faktor Yang Mempengaruhi Kemauan Untuk Membayar Pajak Wajib Pajak Orang Pribadi Yang Melakukan Pekerjaan Bebas Di Kota Pekanbaru. Jurnal Ekonomi, 26(1), 16-28.

Ilhamsyah, R., Endang, M. G. W., \& Dewantara, R. Y. (2016). Pengaruh Pemahaman Dan Pengetahuan Wajib Pajak Tentang Peraturan Perpajakan, Kesadaran Wajib Pajak, Kualitas Pelayanan, Dan Sanksi Perpajakan Terhadap Kepatuhan Wajib Pajak Kendaraan Bermotor. Jurnal Mahasiswa Perpajakan, 8(1).

Lubis, I. (2011). Kreatif Gali Sumber Pajak Tanpa Bebani Rakyat. Jakarta: Kompas Gramedia.

Masruroh, S., \& Zulaikha. (2013). Pengaruh Kemanfaatan NPWP, Pemahaman Wajib Pajak, Kualitas Pelayanan, Sanksi Perpajakan Terhadap Kepatuhan Wajib Pajak (Studi Empiris Pada WP OP Di Kabupaten Tegal). Diponegoro Journal of Accounting, 2(4).

Newcomb, T., \& Heider, F. (1958). The Psychology of Interpersonal Relations. American Sociological Review, 23(6), 742-743. doi: 10.2307/2089062.

Nugroho, R. A., \& Zulaikha. (2012). Faktor-Faktor Yang Mempengaruhi Kemauan Untuk Membayar Pajak Dengan Kesadaran Membayar Pajak Sebagai Variabel Intervening. Diponegoro Journal of Accounting, 1(1).

Nurlaela S. (2014). Pengaruh Pengetahuan Dan Pemahaman, Kesadaran, Persepsi Terhadap Kemauan Membayar Pajak Wajib Pajak Orang Pribadi Yang Melakukan Pekerjaan Bebas. Jurnal Paradigma, 11(2), 89-101. 
The Effect of Willingness to Pay Taxes and the Level of Understanding of Taxpayers on Tax Payment Compliance

Perda Nomor 973/90 Tahun 2012, 'Keputusan Walikota Semarang Nomor 973/90 Tahun 2012 Tentang Penetapan Nilai Sewa Reklame (NSR) Di Kota Semarang' $<$ Bapenda. Semarangkota. go. id>. 